\title{
Pendekatan bermain, intruksi langsung, dan motivasi: Adakah pengaruh keterampilan peserta ekstrakurikuler sepakbola SMA?
}

\author{
Yanuar Dian Pradana a *, Hari Amirullah Rachman a \\ Universitas Negeri Yogyakarta. Jalan Colombo No. 1, Yogyakarta, 55281, Indonesia. \\ a yanuardianp@gmail.com; b harirachman@yahoo.com.au \\ * Coressponding Author.
}

Received: 15 January 2021; Revised: 20 January 2021; Accepted: 22 January 2021

Abstrak: Olahraga sepakbola merupakan salah satu cabang olahraga yang banyak digemari oleh para siswa untuk mengikuti kegiatan ekstrakurikuler. Penelitian ini bertujuan untuk mengetahui perbedaan antara pendekatan bermain dan pendekatan intruksi langsung keterampilan sepakbola, perbedaan keterampilan sepakbola antara peserta ekstrakurikuler yang memiliki motivasi berprestasi tinggi dan motivasi berprestasi rendah dan interaksi antara pendekatan bermain, intruksi langsung, dan motivasi berprestasi terhadap keterampilan sepakbola. Penelitian ini adalah penelitian eksperimen faktorial 2x2. Sampel peserta ekstrakurikuler sepakbola SMA N 2 Purwokerto dan SMA N 5 Purwokerto berjumlah 34 siswa. Instrumen motivasi berprestasi diukur dengan angket motivasi berprestasi dan keterampilan sepakbola diukur dengan Pengembangan David Lee oleh Subagyo Irianto tahun 2010. Teknik analisis data adalah Analisis Varian (ANAVA) dua jalur, dan uji Pairwise Comparisons signifikan $\alpha=$ 0,05 . Hasil penelitian mengungkapkan bahwa ada perbedaan pengaruh yang signifikan yaitu pendekatan bermain dan pendekatan intruksi langsung terhadap keterampilan sepakbola, nilai $p=0.00<$ 0.05 , ada perbedaan yang signifikan hasil keterampilan sepakbola antara peserta ekstrakurikuler yang memiliki motivasi berpretasi tinggi dan motivasi berprestasi rendah, nilai $p=0.004<0.05$, dan ada interaksi antara pendekatan bermain, intruksi langsung dan motivasi berprestasi terhadap keterampilan sepakbola, nilai $\mathrm{p}=0.05 \leq 0.05$.

Kata Kunci: pendekatan bermain, pendekatan intruksi langsung, motivasi, keterampilan sepakbola.

\section{Playing approach, direct instruction, and motivation: Is there effect of SMA football extracurricular skills?}

Abstract: Football is a sport that is favored by many students to take part in extracurricular activities. This study aims to determine the difference between the playing approach and the direct instructional approach to soccer skills, the difference in football skills between extracurricular participants who have high achievement motivation and low achievement motivation, and the interaction between the playing approach, direct instruction, and achievement motivation on football skills. This research is a $2 \times 2$ factorial experimental research. The sample of football extracurricular members at SMA N 2 Purwokerto and SMA N 5 Purwokerto was 34 students. The instrument of achievement motivation was measured by a questionnaire of achievement motivation and football skills were measured by David Lee's Development by Subagyo Irianto in 2010. The data analysis technique was two-way Variant Analysis (ANAVA), and the Pairwise Comparisons test was significant $\alpha=0.05$. The results of the study revealed that there was a significant difference in influence, namely the playing approach and the direct instructional approach to football skills, $p$-value $=0.00<0.05$, there was a significant difference in the results of football skills between extracurricular participants who had high achievement motivation and low achievement motivation, $p$-value $=0.004<0.05$, and there is an interaction between the playing approach, direct instruction and achievement motivation on football skills, $p$-value $=0.05 \leq 0.05$.

Keywords: playing approach, direct instruction approach, motivation, football skills.

How to Cite: Pradana, Y., \& Rachman, H. (2021). Pendekatan bermain, intruksi langsung, dan motivasi: Adakah pengaruh keterampilan peserta ekstrakurikuler sepakbola SMA?. Sepakbola, 1(1), 8-15. doi:http://dx.doi.org/10.33292/sepakbola.v1i1.93 
Sepakbola, 1 (1), 2021, 9

Yanuar Dian Pradana, Hari Amirullah Rachman

\section{PENDAHULUAN}

Olahraga merupakan suatu kegiatan jasmani untuk memperkaya, memperkuat otot-otot, meningkatkan kemampuan, meningkatkan kebugaran dan kesehatan, keterampilan gerak dasar maupun gerak keterampilan. Di dalam ranah pendidikan, olahraga bisa diperoleh dengan ikut melakukan kegiatan intrakurikuler maupun ekstrakurikuler di sekolah. Dalam kegiatan intra sekolah setiap minggu para siswa mengikuti pembelajaran pendidikan jasmani olahraga dan kesehatan (penjasorkes). Kegiatan ekstrakurikuler bertujuan untuk menyalurkan, mengembangkan, dan menambah jam pelajaran khususnya penjas untuk meningkatkan kebugaran jasmani. Olahraga sepakbola merupakan salah satu cabang olahraga yang banyak digemari oleh para siswa untuk mengikuti kegiatan ekstrakurikuler di sekolahnya masing-masing, karena olahraga sepakbola adalah olahraga populer.

Proses kegiatan ekstrakurikuler sepakbola yang diselenggarakan khususnya wilayah SMA Negeri di Purwokerto Timur menggunakan pendekatan bermain dan pendekatan intruksi langsung. Hal ini didasarkan pada wawancara terhadap pelatih kegiatan eksrakurikuler. Hasil didapat SMA Negeri 1 Purwokerto dan SMA Negeri 2 Purwokerto menggunkan pendekatan bermain pada kegiatan ekstrakurikuler sepakbola. SMA Negeri 4 Purwokerto dan SMA Negeri 5 Purwokerto menggunakan pendekatan intruksi langsung pada kegiatan ekstrakurikuler sepakbola. Suasana kegiatan ekstrakurikuler diarahkan agar peserta didik dapat mengembangkan potensi dirinya yang berarti proses pendidikan itu harus berorientasi kepada peserta didik Menurut Subroto, (2006) pendekatan bermain merupakan berlatih yang selalu menekankan kepada proses gamedrill-game, sehingga dengan menggunakan pendekatan bermain akan memotivasi peserta ekstrakurikuler untuk terlibat secara aktif dalam proses berlatih permainan sepakbola. Menurut Rosdiani (2012) pendekatan intruksi langsung merupakan program latihan kegiatan ekstrakurikuler sepakbola yang cara penyampaian gerakan dengan intruksi langsung dari pelatih.

Dalam observasi pelatih yang menggunakan pendekatan intruksi langsung melakukan latihan mengfokuskan terhadap gerakan yang bersifat pengulangan dalam melaksanakan program latihan yang diberikan oleh pelatih. Observasi yang di lakukan penulis juga didukung dengan pendapat dari pelatih-pelatih yang melatih ekstrakurikuler sepakbola SMA Negeri di Purwokerto Timur menyatakan bahwa kelemahan sebagian besar peserta ekstrakurikuler sepakbola ada pada aspek keterampilan dan motivasi peserta didik mengikuti ekstrakurikuler sepakbola. Penelitian terdahulu yang relevan dengan penelitian ini adalah penelitian yang dilakukan Aprilianto dan Tomoliyus (2016) tujuan penelitian untuk menghasilkan buku pedoman bermain sepakbola untuk meningkatkan aspek psikologis (semangat, gembira, dan disiplin) anak usia 12-13 tahun di Yogyakarta. Hasil penelitian mengungkapkan jika model bermain sepakbola anak usia 12-13 tahun efektif untuk meningkatkan aspek psikologis berupa semangat, gembira, dan disiplin siswa dalam melakukan latihan sepakbola.

Dalam kegiatan latihan, antara siswa satu dengan yang lainnya bisa jadi berbeda Dengan kata lain, peserta ekstrakurikuler perlu diberikan motivasi. Menurut Sardiman (2007) motivasi merupakan serangkaian usaha untuk menyediakan kondisi-kondisi tertentu, sehingga seseorang mau dan ingin melakukan sesuatu, dan bila ia tidak suka, maka akan berusaha untuk meniadakan atau mengelakkan perasaan tidak suka itu. Dalam latihan, motivasi dapat dikatakan sebagai keseluruhan daya penggerak di dalam diri peserta ekstrakurikuler yang menimbulkan kegiatan latihan, yang menjamin kelangsungan dari kegiatan latihan dan yang memberikan arah pada kegiatan latihan, sehingga tujuan yang dikehendaki oleh subjek latihan itu dapat tercapai.

Menurut Uno (2006)ada dua faktor yang dapat membuat siswa termotivasi untuk latihan, yaitu: pertama, motivasi latihan berasal dari faktor internal. Motivasi ini terbentuk karena kesadaran diri atas pemahaman betapa pentingnya latihan untuk mengembangkan dirinya dan bekal untuk menjalani kehidupan. Kedua, motivasi latihan dari faktor eksternal, yaitu dapat berupa rangsangan dari orang lain atau lingkungan sekitarnya yang dapat mempengaruhi psikologis orang yang bersangkutan. Menurut Weinberg dan Gould (2007) teori-teori berprestasi dalam pandangan interaksional yang menganggap faktor personal dan situasional sebagai komponen penting dari perilaku. 
Kegiatan ekstrakurikuler untuk peserta didik juga dikaitkan dengan model latihan yang digunakan guru. Model diartikan sebagai kerangka konseptual yang digunakan sebagai pedoman dalam melakukan kegiatan, model dapat dipahami sebagai: (1) suatu tipe atau desain, (2) suatu deskripsi atau analogi yang digunakan untuk membantu proses visualisasi sesuatu yang tidak dapat diamati secara langsung, (3) suatu sistem asumsi-asumsi, data-data, inferensi-inferensi yang dipakai untuk menggambarkan secara matematis suatu objek atau peristiwa, (4) suatu desain yang disederhanakan, (5) suatu deskripsi dari suatu sistem yang nyata atau imajiner, dan (6) penyajian yang diperkecil agar dapat menjelaskan dan menunjukan sifat bentuk aslinya (Sukmadinata, 2015).

Model berlatih antara pendekatan bermain dan intruksi langsung adalah model berlatih yang digunakan dalam penelitian ini khususnya dalam kegiatan ekstrakurikuler sepakbola. Peserta didik memiliki tingkat kecerdasan yang berbeda-beda yang membuat suatu penemuan konsep untuk mempelajari teknik dasar sepakbola. Untuk mengatasi hal tersebut, perlunya motivasi berprestasi dibuat untuk memberikan yang lebih baru dan lebih dapat diterima oleh peserta didik. Menurut Rosdiani (2012) proses pembelajaran pendidikan jasmani akan dikatakan sempurna jika menyangkut tiga aspek pembelajaran: kognitif, afektif, dan psikomotor. Dalam upaya melaksanakan proses latihan sepakbola yang baik, tentu saja upaya yang logis dari seorang pelatih dalam hal pendekatan yang sesuai, mengorganisasikan serta modifikasi fasilitas dan peralatan, jumlah pemain, kompleksitas skill, tujuan permainan dan suasana latihan harus menjadi perhatian dan pertimbangan khusus bagi seorang pelatih.

Penggunaan model latihan yang tepat sangat diperlukan peserta ekstrakurikuler sepakbola agar dapat cepat memahami dan menguasai keterampilan atau teknik dasar permainan sepakbola, selain itu yang terpenting adalah peserta ekstrakurikuler sepakbola merasa senang dan mengikuti proses latihan sepakbola. Penelitian ini bertujuan untuk mengetahui perbedaan antara pendekatan bermain dan pendekatan intruksi langsung keterampilan sepakbola, perbedaan keterampilan sepakbola antara peserta ekstrakurikuler yang memiliki motivasi berprestasi tinggi dan motivasi berprestasi rendah dan interaksi antara pendekatan bermain, intruksi langsung, dan motivasi berprestasi terhadap keterampilan sepakbola. Oleh karena itu peneliti melakukan penelitian tentang pengaruh pendekatan bermain, intruksi langsung, dan motivasi berprestasi terhadap keterampilan sepabola peserta ekstrakurikuler SMA Negeri di Purwokerto Timur.

\section{METODE}

Jenis penelitian ini merupakan penelitian eksperimen dengan menggunakan desain faktorial 2 × 2. (Sudjana, 2002) eksperimen faktorial adalah eksperimen yang bertaraf sebuah faktor dikombinasikan atau disilangkan dengan semua taraf tiap faktor lainnya yang ada dalam eksperimen.

Populasi dalam penelitian ini adalah peserta ekstrakurikuler sepakbola SMA Negeri 2 Purwokerto yang berjumlah 18 siswa dan SMA Negeri 5 Purwokerto yang berjumlah 16 siswa. Sampel dalam penelitian ini adalah siswa peserta kegiatan ekstrakurikuler sepakbola di SMA Negeri 2 Puwokerto dan SMA Negeri 5 Puwokerto. Pengambilan sampel dalam penelitian ini menggunakan random sampling. Menentukan sampel berdasarkan tujuan, sampel masih berada pada kriteria usia 16-18 tahun. Diperoleh 34 siswa sebagai sampel.

Penelitian ini dilaksanakan pada Februari sampai April 2016 dengan frekuensi pertemuan masing-masing kelompok eksperimen 2 kali seminggu yaitu pada hari Kamis dan Jumat. Lamanya latihan 90 menit setiap kali pertemuan, jumlah pertemuan masing-masing kelompok eksperimen 14 kali. Latihan dimulai pukul 15.30 s/d 17.00 WIB Penelitian ini dilakukan di SMA Negeri yang ada di kecamatan Purwokerto Timur Kabupaten Banyumas yaitu SMA Negeri 2 Purwokerto dan SMA Negeri 5 Purwokerto.

Prosedur penelitian eksperimen ini meliputi: (1) Memilih subyek penelitian dengan cara random sampling yaitu SMA Negeri yang ada di Purwokerto Timur; (2) Menentuan sampel dari 34 siswa, selanjutnya mengadakan tes angket motivasi berprestasi untuk pembagian kelompok berlatih yang merupakan variabel atribut. Pertama urutkan skor dari hasil tes yang tertinggi sampai terendah. Selanjutnya tentukan skor bagian atas dengan menggunakan 33\% atas dan 33\% 
bawah dari skor total tes. pendekatan bermain dengan motivasi berprestasi tinggi berjumlah 6 siswa, dan motivasi berprestasi rendah berjumlah 6 siswa. Sedangkan untuk kelompok kontrol yaitu pendekatan intruksi langsung dengan motivasi berprestasi tinggi berjumlah 6 siswa, dan motivasi berprestasi rendah berjumlah 6 siswa, (3) Melakukan pretest keterampilan sepakbola, (4) Melakukan treatment dengan pendekatan bermain dan intruksi langsung, (5) Melakukan postest keterampilan sepakbola.

Tabel 1. Desain Penelitian Metode Eksperimen

\begin{tabular}{lll}
\hline \multirow{2}{*}{ Variabel Atributif } & \multicolumn{2}{c}{ Pendekatan latihan } \\
\cline { 3 - 3 } & Pendekatan Bermain (A1) & Pendekatan Intruksi Langsung (A2) \\
\hline Motivasi berprestai tinggi (B1) & A1B1 & A2B1 \\
Motivasi Berprestasi rendah (B2) & A1B2 & A2B2 \\
\hline
\end{tabular}

Keterangan:

A1B1: Kelompok siswa yang memiliki motivasi berprestasi tinggi dilatih mengunakan pendekatan bermain. A2B1: Kelompok siswa yang memiliki motivasi berprestasi tinggi dilatih mengunakan pendekatan intruksi langsung.

A1B2: Kelompok siswa yang memiliki motivasi berprestasi rendah dilatih mengunakan pendekatan bermain.

A2B2: Kelompok siswa yang memiliki motivasi berprestasi rendah dilatih mengunakan pendektan intruksi langsung.

Instrumen pengumpulan data dalam penelitian ini menggunakan instrumen angket motivasi berprestasi dan tes pengembangan keterampilan sepakbola david lee yang dibuat oleh subagyo irianto tahun 2010. Instrumen penelitian ini menggunakan angket motivasi berprestasi digunakan untuk mengetahui motivasi berprestasi dalam mengikuti latihan ekstrakurikuler sepakbola. Angket untuk meneliti motivasi peserta ekstrakurikuler terdiri dari 4 alternatif jawaban yaitu: SS (sangat setuju), S (setuju), TS (tidak setuju), STS (sangat tidak setuju). Jawaban dari responden diberikan dengan memberi tanda contreng $(\sqrt{ })$ pada kotak yang sudah disediakan. Dalam tes untuk mengukur keterampilan penguasaan teknik-teknik dasar dalam permainan Sepakbola yaitu Tes keterampilan dengan tes Pengembangan David Lee yang dibuat oleh Subagyo Irianto pada tahun 2010.

Teknik analisis data yang digunakan dalam penelitian ini dengan menggunakan ANAVA yaitu dengan menggunakan bantuan program SPSS 20.0 dengan taraf signifikansi 5\% atau 0,05. Uji ini dilakukan untuk mengetahui perbedaan rerata nilai hasil peningkatan antara pretest dan posttest pada kelompok eksperimen dan mengetahui interaksi antara model latihan dan motivasi latihan terhadap keterampilan bolabasket. Setelah dilakukan analisi variansi dan terjadi interaksi yang signifikan maka dilanjutkan dengan menggunakan analisis perbandingan Post Hoc untuk mengetahui kelompok perlakuan yang paling efektif untuk meningkatkan keterampilan.

\section{HASIL DAN PEMBAHASAN}

Hasil

Hasil yang diperoleh dari penelitian berupa data yang merupakan gambaran umum tentang masing-masing variabel yang terkait dalam penelitian. Melalui gambaran umum ini akan nampak kondisi awal dan kondisi akhir dari setiap variabel yang diteliti dengan melakukan pengolahan data setelah data berhasil dikumpulkan selama periode latihan yang telah ditentukan.

Pada Tabel 1 diperoleh data yang akan dijelaskan pada sub-sub bagian berikut: (1)untuk kelompok A1B1 pada tes awal diperoleh rata-rata sebesar 51,4317 setelah dilakukan perlakuan dengan pendekatan bermain didapat rata-rata meningkat menjadi 38,6917 sehingga peningkatan pada kelompok A1B1 sebesar 12,74; (2) untuk kelompok A1B2 pada tes awal diperoleh rata-rata sebesar 55,2850 setelah dilakukan perlakuan dengan pendekatan bermain didapat rata-rata meningkat menjadi 47,4583 sehingga peningkatan pada kelompok A1B2 sebesar 7,8267; (3) untuk kelompok A2B1 pada tes awal diperoleh rata-rata sebesar 54,7400 setelah dilakukan perlakuan dengan pendekatan intruksi langsung didapat rata-rata meningkat menjadi 49,7250 sehingga peningkatan pada kelompok A2B1 sebesar 5,015; (4) untuk kelompok A2B2 pada tes awal diperoleh rata-rata sebesar 63,2600 setelah dilakukan perlakuan dengan pendekatan 
Sepakbola, 1 (1), 2021, 12

Yanuar Dian Pradana, Hari Amirullah Rachman

intruksi langsung didapat rata-rata meningkat menjadi 59,2167 sehingga peningkatan pada kelompok A2B1 sebesar 4,0433.

Tabel 2. Ringkasan Hasil Analisis Statistik Untuk Penggunaan Pendekatan Bermain dan Pendekatan Intruksi Langsung.

\begin{tabular}{ccccc}
\hline Perlakuan & Statistik & Hasil Tes Awal & Hasil Tes Akhir & Peningkatan \\
\hline A1B1 & Jumlah & 493 & 573 & 80 \\
& Rerata & 54,778 & 63,667 & 8,889 \\
SD 1 B2 & SD & 7,190 & 1,658 & 108 \\
& Jumlah & 548 & 656 & 9,818 \\
& Rerata & 49,818 & 59,636 & 174 \\
A1B2 & SD & 7,833 & 1,963 & 21,750 \\
& Jumlah & 398 & 572 & 159 \\
& Rerata & 49,75 & 71,5 & 22,714 \\
A2B2 & SD & 8,225 & 1,604 & \\
& Jumlah & 351 & 510 & 72,857 \\
& Rerata & 50,143 & 1,574 & \\
\hline
\end{tabular}

Keterangan:

A1B1: Kelompok siswa yang memiliki motivasi berprestasi tinggi dilatih mengunakan pendekatan bermain. A2B1: Kelompok siswa yang memiliki motivasi berprestasi tinggi dilatih mengunakan pendekatan intruksi langsung.

A1B2: Kelompok siswa yang memiliki motivasi berprestasi rendah dilatih mengunakan pendekatan bermain.

A2B2: Kelompok siswa yang memiliki motivasi berprestasi rendah dilatih mengunakan pendektan intruksi langsung.

Teknik analisis data adalah Analisis Varian (ANAVA) dua jalur, dan uji Pairwise Comparisons

Uji analisis anava pertama adalah untuk mengetahui bermain dan pendekatan intruksi langsung terhadap keterampilan sepakbola. Berdasarkan hasil perhitungan SPSS 20.0di atas penarikan kesimpulan apabila: (1) Jika $\alpha=0,05$ lebih besar atau sama dengan nilai sig atau [ $\alpha=$ $0,05 \geq s i g$ ], maka Ho diterima, artinya tidak ada perbedaan peningkatan. (2) Jika $\alpha=0,05$ lebih kecil atau sama dengan nilai sig atau $[\alpha=0,05 \leq s i g]$, maka $\mathrm{H}_{0}$ ditolak, artinya ada perbedaan peningkatan yang signifikan. Pada taraf sig diperoleh sebesar 0,000<0,05 hal ini berarti terdapat pengaruh pendekatan bermain dan pendekatan intruksi lagsung terhadap keterampilan sepakbola. Dari analisis lanjutan diperoleh bahwa ternyata pendekatan bermain memiliki peningkatan yang lebih baik dari pada pendekatan intruksi langsung, yaitu dengan rerata 43,075 untuk pendekatan bermain lebih baik dari pada rerata 54,471 untuk pendekatan intruksi langsung. Dengan demikian pendekatan bermain lebih bagus dari pada pendekatan intruksi langsung.

Uji analisis anava perbedaan pengaruh antara pendekatan bermain dan pendekatan intruksi langsung dengan peserta yang memiliki motivasi tinggi dan yang memiliki motivasi rendah. Berdasarkan hasil perhitungan SPSS 20.0di atas penarikan kesimpulan apabila: (1) Jika $\alpha$ $=0,05$ lebih besar atau sama dengan nilai sig atau $[\alpha=0,05 \geq \operatorname{sig}]$, maka Ho diterima, artinya tidak ada perbedaan peningkatan. (2) Jika $\alpha=0,05$ lebih kecil atau sama dengan nilai sig atau $[\alpha=0,05 \leq$ sig], maka $\mathrm{H}_{0}$ ditolak, artinya ada perbedaan peningkatan yang signifikan. Pada taraf sig diperoleh sebesar $0,004<0,05$ hal ini berarti terdapat perbedaan pengaruh antara peserta yang memiliki motivasi tinggi dan yang memiliki motivasi rendah.. Berdasarkan dari nilai signifikansi Univariate Tests sebesar 0,004<0,05 yang berarti bahwa lebih kecil dari taraf signifikan.

\section{Hasil uni analsis anava untuk mencari apakah ada interaksi antara pendekatan bermain dan motivasi berprestasi terhadap keterampilan sepakbola}

Berdasarkan hasil perhitungan SPSS 20.0di atas penarikan kesimpulan apabila: (1) Jika $\alpha=$ 0,05 lebih besar atau sama dengan nilai sig atau $[\alpha=0,05 \geq \operatorname{sig}]$, maka Ho diterima, artinya tidak ada interaksi. (2) Jika $\alpha=0,05$ lebih kecil atau sama dengan nilai sig atau $[\alpha=0,05 \leq s i g]$, maka $\mathrm{H}_{0}$ ditolak, artinya ada interaksi. Pada taraf sig diperoleh sebesar 0,050 $\leq 0,05$ hal ini berarti terdapat 
interaksi yang signifikan antara pendekatan bermain dan motivasi berprestasi terhadap keterampilan sepakbola. Berdasarkan hasil perhitungan Tests of Between-Subjects Effects didapat bahwa taraf signifikansi sebesar $0,050 \leq 0,05$, hal ini menunjukkan bahwa tingkat signifikansi $5 \%$ ada pengaruh bersama antara pendekatan bermain dan motivasi berprestasi terhadap keterampilan sepakbola. Dengan demikian hipotesis 3 yang menyatakan bahwa: Ada interaksi pendekatan bermain dan motivasi berprestasi terhadap keterampilan sepakbola, diterima:

\section{Estimated Marginal Means of posttest}

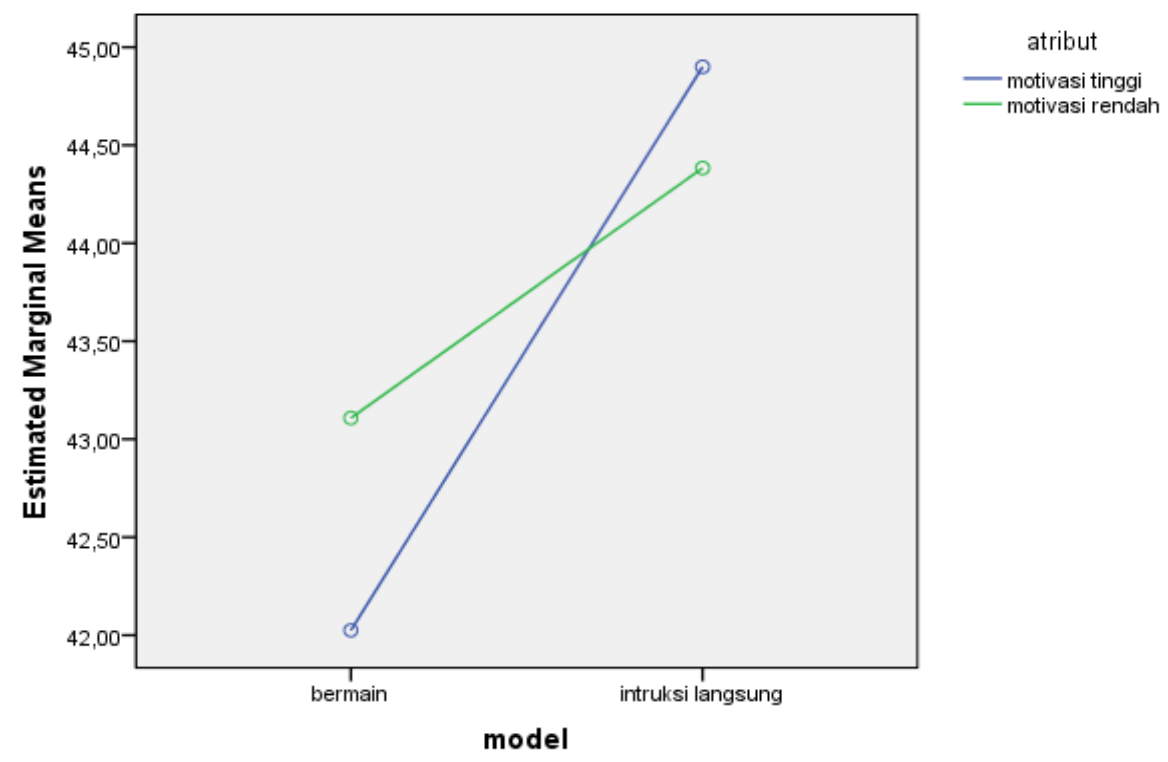

Gambar 1. Bentuk Interaksi Plofile Plots

Berdasarkan gambar di atas, dapat diketahui bahwa bentuk garis perubahan besarnya nilai hasil keterampilan adalah tidak sejajar dan bersilangan. Garis perubahan peningkatan hasil keterampilan sepakbola antar kelompok memiliki suatu titik pertemuan atau persilangan, antara pendekatan bermain dan pendekatan intruksi langsung untuk meningkatkan hasil keterampilan sepakbola. Ini berarti bahwa terdapat interaksi yang signifikan diantara keduanya. Gambar tersebut menunjukan bahwa pendekatan bermain dan pendekatan intruksi langsung berpengaruh terhadap keterampilan sepakbola. Setelah teruji terdapat interaksi antara pendekatan bermain dan motivasi berprestasi terhadap keterampilan sepakbola maka perlu dilakukan uji lanjut dengan menggunakan Pairwise Comparisons. Berdasarkan perhitungan Pairwise Comparison menunjukkan bahwa pasangan-pasangan yang memiliki interaksi atau pasangan yang berbeda secara nyata (signifikan). adalah: (a) pasangan antara BT dengan BR (b) pasangan antara BT dengan LR (c) BR dengan LR (d) pasangan antara LT dengan LR.

\section{Pembahasan}

Berdasarkan hasil penelitian yang didapatkan diketahui bahwa pendektan bermain, intrusi langsung dan motivasi memiliki pengaruh yang baik terhadap keterampilan peserta ekstrakulikuler SMA di Purwokerto Timur. Hasil penelitian yang didapatkan jika dikaitkan dengan penelitian terdahulu memiliki kesamaan hasil penelitian. Sejalan dengan hal ini hasil penelitian Wardana \& Sudarso, (2015) mengungkapkan bahwa peningkatan hasil passing peserta sepakbola esktrakulikuler dipengaruhi dengan adanya pendektan pelatihan melalui instruksi langsung serta peningkatan motivasi yang dilakukan ole pelatih. Pendektan bermain yang dilakukan oleh pelatih terhadap peserta olahraga sepakbola dirasa cukup efektif dalam meningkatkan kemampuan dalam bermain sepakbola siswa MAN Jakarta (Saputro, 2018). Motivasi berprestadi yang diterapkan kepada pemain sepakbola terbukti memiliki pengaruh yang signifikan terhadap keberhasilan (Darmawan et al., 2019). Filho et al. (2018) mengungkapkan jika motovasi berprestasi yang sifatnya intrinsik mempengaruhi keberhasilan game pertandingan dalam sepak bola, semakin 
tinggi motivasi yang dimiliki akan semakin besar peluang dalam meraih keberhasil dalam game selanjutnya dibanding-an dengan game yang telah berlangsung sebelumnya.

Hasil analisis motivasi berprestasi juga mengungkapkan jika seoarang antel yang emmiliki motivasi tinggi akan mempengaruhi bagaimana penalipanya dalam ekstrakulikler. Jika dilihat hasil penelitian terdahulu memiliki persamaan seperti penelitian, Apriansyah et al. (2017) mengungkapkan jika motivasi bertanding ataupun berprestasi merupakan salah satu komponen penting dalam mewujudkan keberhasilan atlet. Kemudian hasil penelitian juga mengungkapkan terdapat hubungan yang signifikan terhadap metode latihan dengan intruksi langsung dan motivasi berprestasi terhadp kemampuan sepakbola siswa ekstrakulikuler. Sejalan dengan hasil analisis data, beberapa penelitian menyebutkan hal serupa. Metode latihan secara langsung dan motivasi berprestasi berhubungan dengan kemampuan meningkat dalam menggiring bola di permainan sepak bola lampung timur, lebih lanjut diungkapkan hal ini juga memoengaruhi keberhasilan pemain sepakbola dilapangan (Zulkarnain \& Haqiyah, 2018). Meto-de latihan serta motivasi berpresati adalah komponen penting yang harus dimiliki atlet guna mendukung keberhasilan dalam melakukan olahraga. Lebih lanjut diungkapkan bahwa kedua komponen ini perlu diperhatikan dan dilatih dengan baik (Amirzan \& M. Yahya, 2019). Secara keseluruhan metode latihan test session memiliki pengaruh yang lebih baik dibanding dengan metode latihan practice session. Sedangkan bagi atlet/siswa yang mempunyai motivasi berpres-tasi tinggi hendaknya dilatih dengan metode test session jika ingin meningkatkan keterampilan menendang dalam sepak bola. Sedangkan bagi atlet/siswa yang mempunyai motivasi berprestasi rendah, dapat menerapkan kedua metode latihan untuk meningkatkan keterampilan menendang dalam sepak bola, tetapi cenderung akan lebih baik jika dilatih menggunakan metode latihan practice session, hal ini direkomendasikan jika berdasarkan rata-rata skor yang di dapat, serta pemenuhan prasyarat yang diperlukan seperti pembahasan yang disampaikan sebelumnya. (Efendi, 2016).

\section{SIMPULAN}

Berdasarkan hasil penelitian dan hasil analisis data yang telah dilakukan, diperoleh kesimpulan ada perbedaan pengaruh yang signifikan yaitu pendekatan bermain dan pendekatan intruksi langsung terhadap keterampilan sepakbola. Hasil penelitian diharapkan dapat menjadi rujukan bagi pelatih atau pembina olahraga yaitu pendekatan bermain memiliki pengaruh yang lebih baik dalam meningkatkan keterampilan sepakbola, sehingga pelatih atau pembina olahraga sebaiknya memilih pendekatan bermain dalam upaya meningkatkan keterampilan sepakbola. Pendekatan bermain dan pendekatan intruksi langsung perlu memperhatikan faktor motivasi berprestasi serta sarana dan prasarana yang tersedia dalam meningkatkan keterampilan sepakbola. Pelatih atau pembina olahraga disarankan merancang program latihan yang tepat dan terencana sesuai dengan cabang olahraga masing-masing, mengingat kebutuhan hasil keterampilan setiap cabang olahraga berbeda-beda dan belum tentu suatu pendekatan berlatih sesuai atau cocok bagi semua kelompok.

\section{DAFTAR PUSTAKA}

Amirzan, A., \& M. Yahya, M. Y. (2019). Pengaruh metode latihan dan motivasi berprestasi terhadap kemampuan teknik lari 110 gawang putera. Jurnal Serambi Ilmu, 20(1), 19. https://doi.org/10.32672/si.v20i1.993

Apriansyah, B., Sulaiman, S., \& Mukarromah, S. B. (2017). Kontribusi motivasi, kerjasama, kepercayaan diri terhadap prestasi atlet sekolah sepakbola Pati Training Center di Kabupaten Pati. Journal of Physical Education and Sports, 6(2), 101-107. https://journal.unnes.ac.id/sju/index.php/jpes/article/view/17358

Aprilianto, M., \& Tomoliyus, T. (2016). Pengembangan model bermain sepakbola untuk meningkatkan aspek psikologis anak usia 12 -13 tahun di Yogyakarta. Jurnal Keolahragaan, 4(1), 34-46. https://doi.org/10.21831/jk.v4i1.8138

Darmawan, G., Ridwan, M., \& Herdyanto, Y. (2019). Motivation learning of football : Application small sided games. Proceedings of the 1st International Conference on Education Social 
Sciences and Humanities (ICESSHum 2019), 335(ICESSHum), 92-95.

https://doi.org/10.2991/icesshum-19.2019.15

Efendi, R. (2016). Pengaruh metode latihan practice session, test session dan motivasi berprestasi terhadap keterampilan menendang dalam sepak bola. JUDIKA (Jurnal Pendidikan Unsika), 4(1), 91-106.

https://journal.unsika.ac.id/index.php/judika/article/view/239

Filho, M. J. de S., Albuquerque, M. R., Costa, I. T. da, Malloy-Diniz, L. F., \& Costa, V. T. da. (2018). Comparação do nível de motivação de atletas de futebol com alto e baixo tempo jogado nas partidas da categoria sub-20. Journal of Physical Education, 29(1), 1-10. https://doi.org/10.4025/jphyseduc.v29i1.2911

Rosdiani. (2012). Perencanaan pembelajaran dalam pendidikan jasmani dan kesehatan. Alfabeta.

Saputro, A. K. (2018). Peningkatan hasil belajar sepak bola melalui pendekatan bermain kelompok. Jurnal Penjakora Fakultas Olahraga Dan Kesehatan, 5(1), 47-53. https://doi.org/10.23887/penjakora.v5i1.14500

Sardiman, A. M. (2007). Interaksi dan motivasi belajar mengajar. PT. Raja Grafindo Persada.

Subroto, S. (2006). Pembelajaran keterampilan dan konsep olahraga di sekolah dasar. Departemen Pendidikan Nasional Republik Indonesia.

Sudjana, N. (2002). Penilaian hasil proses belajar mengajar. PT. Remaja Rosda Karya.

Sukmadinata, N. S. (2015). Metode penelitian pendidikan. PT Remaja Rosdakarya.

Uno, B. H. (2006). Teori motivasi \& pengukurannya. Bumi Aksara.

Wardana, D. N. K., \& Sudarso, S. (2015). Peningkatan hasil belajar passing pada permainan sepakbola melalui metode pembelajaran langsung siswa kelas V SDN Tulangan II Sidoarjo. Jurnal Pendidikan Olahraga Dan Kesehatan, 3(1), 147-153. https://jurnalmahasiswa.unesa.ac.id/index.php/jurnal-pendidikanjasmani/article/view/13502

Weinberg, R. S., \& Gould, D. (2007). Fundations of sport and exercise psychology. Human Kinetics.

Zulkarnain, F., \& Haqiyah, A. (2018). Pengaruh metode latihan dan motivasi berprestasi terhadap keterampilan menggiring bola pada permainan sepak bola. Perspektif Ilmu Pendidikan, 32(1), 15-21. https://doi.org/10.21009/PIP.321.3 